\title{
Genetic Diversity of Selected Commercial Freshwater Fishes Based On Phospholipase C Zeta (Plc $\zeta$ ) Expression
}

\author{
NA Norbidin ${ }^{1}$, YK Cheah ${ }^{1}$, S Sukardi ${ }^{1}$ \\ ${ }^{1}$ (Department of Biomedical Sciences, Faculty of Medicine and Health Sciences, Universiti Putra Malaysia, \\ Malaysia)
}

\begin{abstract}
Egg activation is important to help release the egg from meiotic arrest and blockpolyspermy. It is linked with an increase in intracellular egg calcium ions $\left(\mathrm{Ca}^{2+}\right)$ in almost all species studied and current studies imply that the mammalian sperm factor involved is a sperm-specific phospholipase C zeta, PLC $\zeta$. Here, we report the identification of PLC $\zeta$ in the testis and egg of LampamJawa. Our findings provide the evidence that $P L C \zeta$ is present in the species of male and female LampamJawa (Barbonymusgonionotus). For this study, six types of commercial freshwater fish were selected i.e. Red Tilapia (Oreochromis sp. Red Tilapia), Black Tilapia (Oreochromismossambicus), Catfish or Keli (Ictaluruspunctatus), Silver Catfish or Patin (Pangasiuspangasius), Snakehead Fish or Haruan (Channastriatus) and Silver Barb or LampamJawa (Barbonymusgonionotus). The objectives of this study were to isolate the mRNA from the gonads of freshwater fishes, to identify and amplify

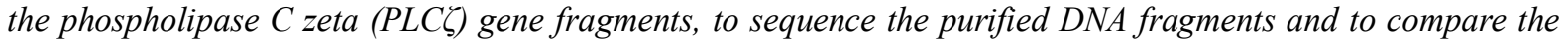

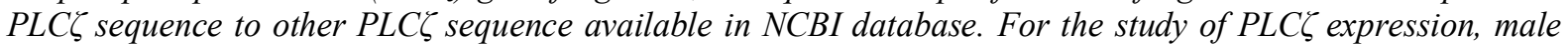
and female LampamJawa showed bands at around 420bp in agarose gel electrophoresis suggesting the presence of PLC gene while no significant bands were found in other types of fishes used in this study.
\end{abstract}

Keywords :Egg, freshwater fish,phospholipase c zeta, sequence, testis

\section{INTRODUCTION}

Sixtypes of freshwater fishes were selected for this study namely Tilapia Merah (Oreochromis sp. Red Tilapia), Tilapia Hitam (Oreochromismossambicus), Catfish or Keli (Ictalaruspunctatus), Silver Catfish or Patin (Pangasiuspangasius), Snakehead Fish or Haruan (Channastriatus) and Silver Barb or LampamJawa (Barbonymusgonionotus). Selection of these fishes were based on the fact that they were commonly found in Malaysia and easily accessible at wholesale markets, night markets, supermarkets, fish farms and aquarium pet shops. Freshwater fishes are an economically important food because of its high nutritional value, delicious taste and the wild types can easily be caught in rivers, paddy fields and mining pools. The specific objectives of this study were to isolate the mRNA from the gonads of freshwater fishes, to identify and amplify the phospholipase $\mathrm{C}$ zeta $(\mathrm{PLC} \zeta)$ gene fragments, to sequence the purified DNA fragments and to compare the PLC $\zeta$ sequence to other PLC $\zeta$ sequence available in NCBI database.

Phospholipase c zeta (PLC $)$ is a phospholipase C (PLC) which is sperm-specific and expressed as mRNA in testis as shown from studies in chicken, nile tilapia, medaka fish and mammalian species (Cox et al., 2002; Saunders et al., 2002; Coward et al., 2003, 2005; Ito et al., 2008; Mizushima et al., 2009; Coward et al., 2011). In sperm, PLC $\zeta$ is expressed as a protein (Fujimoto et al., 2004; Grasa et al., 2008; Coward et al., 2011) as well as in their spermatogenic precursors (Heytens et al., 2009, 2010; Coward et al., 2011) matching the hypothesis of the soluble sperm factor(Swann, 1990; Coward et al., 2011). This study was carried out to detect the presence of PLC $\zeta$ in commercially available freshwater fishes such as LampamJawa, Haruan, Keli, Patin, Tilapia Hitam and Tilapia Merah. Currently, no PLC $\zeta$ study was conducted in freshwater fishes in Malaysia therefore this study should provide a basis for future research in fish PLC $\zeta$.

\section{METHODS}

2.1Sample Collection

The six types of commercial freshwater fishes selected for this study i.e., Keli or Catfish (Ictalaruspunctatus), Patin or Silver Catfish (Pangasiuspangasius), Haruan or Snakehead Fish (Channastriatus), LampamJawa or Silver Barb (Barbonymusgonionotus), Tilapia Merah or Red Tilapia (Oreochromis sp. Red Tilapia) and Tilapia Hitam (Oreochromismossambicus) werebred in commercial fish farms in the northern part of peninsular Malaysia.For each fish species, ten (10) male and 10 female freshwater fishes were collected. The total number of fishes is shown in Table1.

All the testes and eggs were crushed into powder form by using a conventional grinding method. The powdered testes and eggs were place into a centrifuge tube with a known weight. Then the tube was reweighed. 
The exact weight of the sample was obtained by deducting the weight of the centrifuge tube from the total weight of both sample and tube.

\subsection{RNA Extraction}

Extraction of RNA or Ribonucleic acid extraction was performed using Total RNA extraction kit of easy-BLUE ${ }^{\text {TM }}$ (Intron Biotechnology, Korea). Briefly $50-100 \mathrm{mg}$ of fresh tissue was prepared. Approximately $1 \mathrm{ml}$ of easy-BLUETM reagent was added and tissue sample was homogenized using a homogenizer. The sample was vortexed vigorously at room temperature for $10 \mathrm{sec}$. Once all samples were lysed, it was stored at $4{ }^{\circ} \mathrm{C}$ and is stable for up to a week. Upon use, approximately $200 \mu 1$ of chloroform was added and vortexed. Approximately $400 \mu \mathrm{l}$ of the upper fluid was transferred to an empty $1.5 \mathrm{ml}$ tube after spinning the solution at $13,000 \mathrm{rpm}\left(4^{\circ} \mathrm{C}\right)$ for 10min. Approximately $400 \mu 1$ of isopropanol (2-propanol) was added and mixed well by inverting the tube 23 times and left at room temperature for $10 \mathrm{~min}$. The upper layer was removed to obtain RNA pellet after spinning the solution at $13,000 \mathrm{rpm}\left(4^{\circ} \mathrm{C}\right)$ for $5 \mathrm{~min}$. Then, approximately $1 \mathrm{ml}$ of $75 \%$ absolute ethanol was added and the solution was mixed well by inverting the tube 2-3 times. The mixtures were centrifuged for $5 \mathrm{~min}$ at $10,000 \mathrm{rpm}\left(4^{\circ} \mathrm{C}\right)$. The upper layer was discarded and the remaining RNA pellet was dried for $5 \mathrm{~min}$ at room temperature. The RNA was dissolved using 20-50 $\mu 1$ of DEPC treated distilled water.

\subsection{Spectrophotometric Quantitation of RNA}

The spectrophotometer was blanked at $260 \mathrm{~nm}$ with RNase free water. A dilution of RNA sample at 1:50 was prepared ( $1 \mu \mathrm{l}$ of RNA with $49 \mu \mathrm{l}$ of RNase free water) and the sample was mixed thoroughly. The spectrophotometric reading was taken and the concentration and purity of RNA sample was noted.

\subsection{Preparing for Two-Step RT-PCR reactions}

Two kits were used to perform the RT-PCR. The kits are TetrocDNA Synthesis Kit and MyFi ${ }^{\mathrm{TM}}$ Mix. To generate cDNA from an RNA template, the TetrocDNA Synthesis Kit was used. The cDNA synthesis was performed according to manufacturer's protocol. The MyFi ${ }^{\mathrm{TM}}$ Mix on the other handwas specifically designed for amplification of up to $10 \mathrm{~kb}$ of genomic DNA in a ready-to-use $2 \mathrm{x}$ mix newly developed to obtain higherfidelity PCR products.

The primers used to amplify fragments from PLC $\zeta$ were derived from a study by Coward et al. (2011) using ovarian and testicular cDNA prepared from medaka fish total RNA. The primer for beta-actin gene used was also derived from the same study. The sequence for forward primer is 5'-AACACGCCTTTGAGGTTTCA$3^{\prime}$ and the reverse primer is5'-TAAGGTCCATAGGCAAACCCA-3'.The forward sequence for beta-actin is 5'CCTCCGGTCGTACCACTGGTA-3' and the reverse sequence is 5'-CAACGGAAGGTCTCATTGCCGATC $3^{\prime}$.

\subsection{Agarose Gel Electrophoresis}

By mixing $0.6 \mathrm{~g}$ of agarose powder with $40 \mathrm{ml}$ of $1 \mathrm{X}$ TBE solution, $1.5 \%$ agarose gel electrophoresis was prepared. Electrophoresis was conducted under $100 \mathrm{~V}$ for 45 minutes. Gels were stained with ethidium bromide $(\mathrm{EtBr})$ prior gel documentation.

\subsection{Gel Documentation}

Alpha Imager ${ }^{\mathrm{TM}} 2200$ was used and the gel was placed at the center of the stage for gel documentation. The image of the gel was captured in digital format after the gel was well positioned.

\section{$2.8 \quad$ Gel Extraction}

Under the UV transluminator, appropriate bands obtained from the electrophoresis gel was placed, sliced and prepared for gelextraction. By using GeneAll ${ }^{\circledR}$ Expin $^{\mathrm{TM}}$ Gel SV Protocol kit according to protocol provided by the manufacturer, the gel extraction was carried out.

\subsection{Sequencing}

To obtain the gene sequence, the DNA solution from gel extraction was sent to First BASE Laboratories SdnBhd(Malaysia) for sequencing. FinchTV was used to analyze the results of sequencing and the sequence analyzed was then identified by BLAST at database of gene bank in NCBI.

\subsection{Dendrogram}

Phospholipase C zeta (PLC $\zeta$ ) banding profiles were analyzed using BioNumerics software. Pearson coefficient was applied to investigate the relation of the PLC $\zeta$ banding profiles among these different types of freshwater fishes. At the end of this process, the software will produce the dendrogram. Similarity based approach was applied to analyzed the dendrogram generated. 


\section{RESULTS AND DISCUSSION}

3.1 Agarose Gel Electrophoresis

Fig. 1 depicts the result of agarose gel electrophoresis for the detection of phospholipase c zeta (PLC $\zeta$ ) in tissues of freshwater fishes. The samples were from testes and eggs of male and female freshwater fishes. The target PCR products for PLC $\zeta$ were between $400 \mathrm{bp}$ to $500 \mathrm{bp}$ and from the result obtained, we could see that the band obtained at approximately 420bp was suggested to be thePLC $\zeta$ gene. However, PLC $\zeta$ was only detected in both male and female LampamJawa and not in the other fish species used in this study. This finding agrees with Coward et al. (2011) who reported the presence of PLC $\zeta$ in ovaries of pufferfish. The PCR products of male and female PLC $\zeta$ LampamJawa were then outsourcedfor sequencing.

Probably the reason whyPLC $\zeta$ was not detected in the other freshwater fishes may be due to the fact that the fish hadnot mature fully. These fishes used were bred in commercial fish farms where the practice of injecting growth hormones to boost their size and speed up their growth is common. Therefore, their gonads may not be fully developed. Normally, fish bred in the wild take 5 to 6 months to mature fully while farm bred fishes takes less than 5 months. The farm-bred fish also looked bigger despite their young age. Therefore, this may be one of the reasons why PLC $\zeta$ is not detectedin the species of Patin, Keli, Haruan, Tilapia Hitam and Tilapia Merah used in this study.

\subsection{Dendrogramof PLC $\zeta$ from different species of mammals and non-mammals}

Fig. 2 depicts the results obtained from the dendrogram of freshwater fishes' PLC $\zeta$. The result showed the percentage of similarity generated from dendrogram for different species of animals. Many different species of animal PLC $\zeta$ were used to provide more data for better result comparison. The sequencing result of male and female LampamJawa(data not shown)was used to generate the dendrogram. In addition, from the dendrogram we can see that the highest percentage of similarity belongs to the cluster of Takifugurubripes/Tetraodonnigroviridis which are the species of pufferfish and cluster of Bostaurus(bovine)/Susscrofa (wild boar) with similarity of $81 \%$.

This high percentage raised question as how this two clusters are related as the earlier is from nonmammalian (fish) and the latter is mammalian. Additionally, when compared to the PLC $\zeta$ of other species, male LampamJawa (ML) exhibits $25 \%$ similarity to different animals and clusters. First of all, there is $25 \%$ similarity between male LampamJawa and Ranarugosa (wrinkled frog). Frog is an amphibian which does live in water suggesting that it can also be related to male LampamJawa in term of living habitats.

Furthermore, there is also $25 \%$ similarity between male LampamJawa and cluster of Takifugurubripes/Tetraodonnigroviridis(pufferfish). Although both are fishes, they differ in living conditions whereby the male LampamJawais a freshwater fish while the pufferfish is a seawater fish. This two living conditions differ greatly but they maybe related in some ways. Additionally, male LampamJawa is also similarly related (25\%) to different clusters of Coturnix japonica/Gallus gallus,Cricetulusgriseus/Mesocricetusauratus, Musmusculus/Rattusnorvegicus, Macacamulattavar 1/Macacamulattavar 2, Nomascusleucogenys, Pongoabelii, Homo Sapiens/Pan troglodytes, Canis lupus familiaris, Bostaurus/Susscrofa. However, there is only 5\% similarity between female LampamJawa (FL) and these clusters. Further research need to be conducted to confirm these findings.

In this study, we have shown that PLC $\zeta$ is present in both the ovaries and testes of freshwater fishes from the species of LampamJawa. The band obtained from this study for male and female LampamJawawasapproximately 420bp. This finding agrees with the study by Coward (2011) wherePLC $\zeta$ is present not only in testis but also in ovary of freshwater fishes. However, in our study, PLC $\zeta$ is only detected in LampamJawa and not in Tilapia as reported by Coward et al., (2003). It is also not present in the other types of fishes used in this study.

In all species studied, PLC Çis not a sperm-specific PLC and inquiries were raised on their functional role, mechanism of action as well as factors governing tissue-specific pattern of PLC $\zeta$ expression. Whether egg activation is stimulated by soluble "sperm factor" or caused by an interaction at the egg surface between an egg receptor and a sperm ligand that activated an egg PLC remains a major historical debate (Evans and Kopf, 1998; Miyazaki and Ito, 2006; Parrington et al., 2007; Kashir et al., 2010; Coward et al., 2011). 


\section{TABLE AND Figures}

Table 1: The Total Number of Freshwater Fishes $(n=120)$

\begin{tabular}{|c|c|c|}
\hline Freshwater fishes & Number of male & Number of female \\
\hline Keli & 10 & 10 \\
\hline Patin & 10 & 10 \\
\hline Haruan & 10 & 10 \\
\hline LampamJawa & 10 & 10 \\
\hline Tilapia Merah & 10 & 10 \\
\hline Tilapia Hitam & 10 & 120 \\
\hline
\end{tabular}

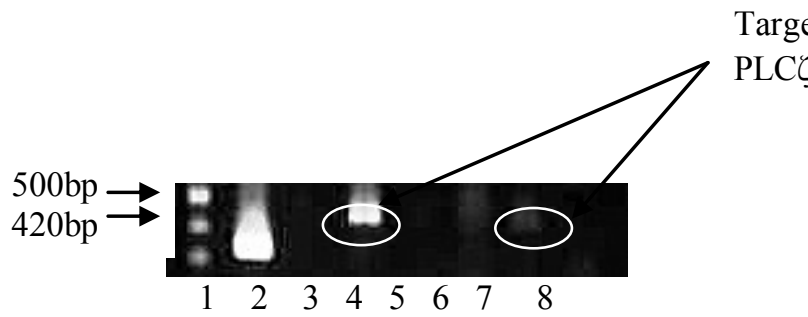

Target PCR product of

igure 1: Tissue expression of freshwater fish phospholipase C zeta (PLC $\zeta$ ) as detected by Two-Step RT-PCR. Target PCR product is between 400bp to 500bp. Lane 1 - 100bp ladder, Lane 2 - beta actin. Lane 3 - male Red Tilapia, Lane 4 - male LampamJawa, Lane 5 - male Keli, Lane 6 -female Red Tilapia, Lane 7 - female LampamJawa, and Lane 8 - female Keli.

$$
\begin{array}{lllllllllllllllllllll}
0 & 5 & 10 & 15 & 20 & 25 & 30 & 35 & 40 & 45 & 50 & 55 & 60 & 65 & 70 & 75 & 80 & 85 & 90 & 95 & 100
\end{array}
$$

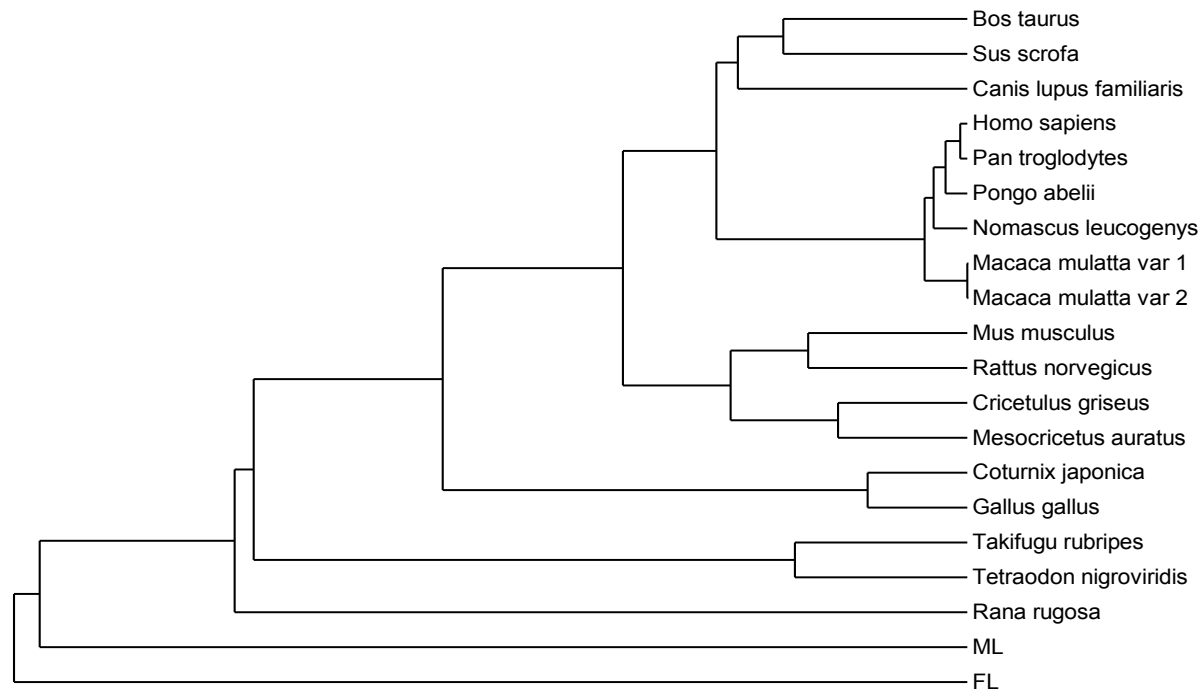

Figure 2: Dendrogram of phospholipase $\mathrm{C}$ zeta (PLC $\zeta$ ) sequence from different animals [Percentage of similarity (\%)]. ML - Male LampamJawa FL - Female LampamJawa

\section{CONCLUSION}

This study's objectives were set to detect, isolate, amplify and sequence the phospholipase C zeta (PLC $\zeta$ gene fragments and to compare the PLC $\zeta$ sequence to other PLC $\zeta$ sequence available in NCBI database. The agarose gel electrophoresis has proven the target PCR product of PLC $\zeta$ gene to be 420bp in LampamJawa. Therefore dendrogram generated using the sequence obtained from the purified gene fragments of PLC $\zeta$ and used to conduct the PLC $\zeta$ banding profile analysis allows the investigation of similarities between the PLC $\zeta$ obtained in the study with other PLC $\zeta$ sequence available in the database. The finding of PLC $\zeta$ in LampamJawa has improved our knowledge concerning PLC $\zeta$ in freshwater fishes.

Acknowledgements

The authors thanked the Felda Foundation for the research grant on PLC $\zeta$. 


\section{REFERENCES}

(1). Coward K, Campos-Mendoza A, Larman M, Hibbitt O, McAndrew B, Bromage N, Parrington J. (2003). Teleost fish spermatozoa contain a cytosolic protein factor that induces calcium release in sea urchin egg homogenates and triggers calcium oscillations when injected into mouse oocytes. BiochemBiophys Res Commun305: 299-304.

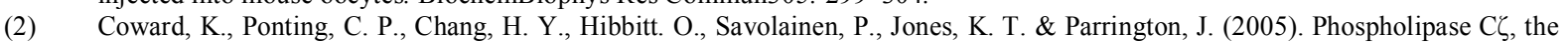
trigger of egg activation in mammals, is present in a non-mammalian species.Journal of Reproduction, 130,157-163.

(3) Coward, K., Ponting, C. P., Zhang, N., Young, C., Huang, C., Chou, C. \&Parrington, J. (2011). Identification and functional analysis of anovarian form of the egg activation factor phospholipase C zeta (PLC $\zeta$ ) in pufferfish. Journal of Molecular Reproduction and Development, 78,48-56.

(4) Cox, L. J., Larman, M. G., Saunders, C. M., Hashimoto, K., Swann, K. \& Lai, F. A. (2002). Sperm phospholipase c-zeta from humans and cynomolgus monkeys triggers $\mathrm{Ca}^{2+}$ oscillations, activation and development of mouse oocytes.Journal of Reproduction, 124,611-623.

(5) Evans, J. P., \& Kopf, G. S. (1998). Molecular mechanisms of sperm-egg interactions and egg activation.Journal of Andrologia, 30, 297-307.

(6) Fujimoto, S., Yoshida, N., Fukui, T., Amanai, M., Isobe, T., Itagaki, C. \& Perry, A. C. (2004). Mammalian phospholipase Cל induces oocyte activation from the sperm perinuclearmatrix.Journal of Developmental Biology, 274, 370-383.

(7) Grasa, P., Coward, K., Young, C. \& Parrington, J. (2008). The pattern of localization of the putative oocyte activation factor, phospholipase $\mathrm{C} \zeta$, in uncapacitated, capacitated, and ionophore-treated human spermatozoa.Journal of Human Reproduction, 23,2513-2522.

(8) Heytens, E., Parrington, J., Coward, K., Young, C., Lambrecht, S., Yoon, S. Y\& De-Sutter, P. (2009). Reduced amounts and abnormal forms of phospholipase C zeta (PLC $\zeta$ ) in spermatozoa from infertile men. Journal of Human Reproduction,24,2417-2428.

(9) Heytens, E., Schmitt-John, T., Moser, J. M., Jensen, N. M., Soleimani, R., Young, C.\&De-Sutter, P. (2010). Reduced fertilization after ICSI and abnormal phospholipase C zeta presence in spermatozoa from the wobbler mouse.Journal of Reproduction Biomed Online, 21, 742-749.

(10) Ito, M., Shikano, T., Kuroda, K. \& Miyazaki, S. (2008). Relationship between nuclear sequestration of PLC zeta and termination of PLC zeta-induced $\mathrm{Ca}^{2+}$ oscillations in mouse eggs.Journal of Cell Calcium,44, 400-410.

(11) Kashir, J., Heindryckx, B., Jones, C., De-Sutter, P., Parrington, J. \& Coward, K. (2010). Oocyte activation, phospholipase C zeta and human infertility. Journal of Human Reproduction Update, 16, 690-703.

(12) Miyazaki, S., \& Ito, M. (2006). Calcium signals for egg activation in mammals. Journal of Pharmacological Sciences, 100, 545552 .

(13) Mizushima, S., Takagi, S., Ono, T., Atsumi, Y., Tsukada, A., Saito, N. \& Shimada, K. (2009). Phospholipase Czeta mRNA expression and its potency during spermatogenesis for activation of quail oocyte as a sperm factor.Journal of Molecular Reproduction and Development, 76, 1200-1207.

(14) Parrington, J., Davis, L. C., Galione, A. \& Wessel, G. (2007). Flipping the switch: how a sperm activates the egg at fertilization.Journal ofDevelopment Dynamics, 236, 2027-2038.

(15) Saunders, C. M., Larman, M. G., Parrington, J., Cox, L. J., Royse, J., Blayney, L. M.\&Lai, F. A. (2002). PLC $\zeta$ : a sperm-specific trigger of $\mathrm{Ca}^{2+}$ oscillations in eggs and embryo development.Journal ofDevelopment, 129, 3533-3544.

(16) Swann, K. (1990). A cytosolic sperm factor stimulates repetitive calcium increases and mimics fertilization in hamster eggs.Journal of Development, 110, 1295-1302. 